\title{
Pengembangan Konsep Kelembagaan sebagai Upaya Rejuvenasi Kawasan Wisata Alam Ranu Grati di Kabupaten Pasuruan
}

\author{
Dian Rahmawati, Hertiari Idajati, Ema Umilia, Ardy M. Navastara, Theresia D. Tambunan, Elok W. \\ Safitri \\ Departemen Perencanaan Wilayah dan Kota, Fakultas Arsitektur, Desain dan Perencanaan \\ Institut Teknologi Sepuluh Nopember \\ e-mail: d_rahmawati@urplan.its.ac.id
}

\begin{abstract}
Abstrak - Kawasan wisata alam Ranu Grati Pasuruan merupakan salah satu danau vulkanik yang terletak di dataran rendah dan memiliki kekayaan berupa sumber daya air yang hingga kini masih menunjang kehidupan masyarakat yang tinggal di sekitarnya dan pemandangan alam yang mengelilingi danau tersebut. Pengelolaan yang kurang optimal telah mendorong kawasan Ranu Grati saat ini mengalami fase stagnan menuju decline jika dilihat dari tipologi Butler. Kualitas air danau menurun akibat limbah keramba dan rumah tangga yang memenuhi daerah sempadan danau, beberapa ladang dan bekas kegiatan pertambangan pasir oleh masyarakat juga berpengaruh ke kualitas air danau, selain itu kegiatan pariwisata juga sangat terbatas perolehannya dalam mendapatkan pengalaman maupun kesempatan terlibat dalam aktivitas pariwisata kecuali jika ada acara tertentu.
\end{abstract}

Artikel ini merupakan bagian dari penelitian yang berjudul Kajian Pengembangan Kawasan Ranu Grati. Tujuan dari penulisan artikel ini adalah mendeskripsikan arahan pengembangan Ranu Grati dilihat dari segi kelembagaan pariwisata sebagai upaya merejuvenasi kawasan Ranu Grati yang saat ini berposisi di fase stagnan menuju decline. Tahapan dari penulisan adalah (1) menyusun faktor yang berpengaruh terhadap menurunnya kondisi kawasan wisata Ranu Grati dengan metode Delphi (2) merumuskan arahan pengembangan Ranu Grati dari segi kelembagaan yang meliputi pemerintah, swasta dan masyarakat dengan metode pendekatan quadriple helix diintegrasikan dalam konsep zonasi kawasan. Hasil yang ditemukan didapatkan: (1) Faktor yang berpengaruh terhadap menurunnya kondisi kawasan wisata Ranu Grati yaitu potensi SDM yang belum seimbang, peran serta masyarakat yang masih rendah, dan koordinasi antar stakeholder yang kurang optimal; (2) Zonasi kawasan wisata Ranu Grati yang terintegrasi dengan konsep pengembangan fungsi kelembagaan yang terbagi dalam ruang inti dan ruang pendukung.

Kata Kunci-Kawasan Wisata Alam, Kelembagaan, Rejuvenasi

\section{PENDAHULUAN}

$\mathrm{D}$ ANAU Ranu Grati merupakan kawasan wisata alam yang terletak di Kabupaten Pasuruan yang berada diantara 3 desa yaitu Desa Sumberdawesari, Desa Ranuklindungan, dan Desa Gratitunon, Kecamatan Grati. Potensi air Danau Ranu Grati dimanfaatkan sebagai sarana pengembangan wisata, perikanan, dan pertanian (irigasi). [2] Dari ketiga usaha tersebut, usaha perikanan dan pertanian yang telah berjalan hingga saat ini. Sedangkan untuk usaha pariwisata, meski Ranu
Grati pernah dikembangkan sebagai wahana wisata air, namun sampai saat ini perkembangan wisata Ranu Grati masih kurang maksimal. Sejak tahun 2000, pihak pemerintah Kabupaten Pasuruan telah berupaya mengembangkan Ranu Grati menjadi wahana wisata air seperti mengadakan kegiatan lomba perahu naga se-Jawa-Bali dan menyediakan fasilitas seperti sepeda air, perahu dan sebagainya. Daya Tarik Ranu Grati tidak hanya berasal dari keindahan alam nya saja namun juga kekayaan kebudayaan masyarakat lokal yang sering mengadakan kegiatan tradisional atau upacara kebudayaan di kawasan Danau Ranu Grati seperti upacara larung sesaji. [3] Perkembangan suatu kawasan wisata alam termasuk Ranu Grati dapat dilihat dari ketersediaan sarana dan prasarana pendukung, aksesibilitas, jumlah pengunjung dan indikator lainnya. Berdasarkan Tambunan (2016), dalam penelitian tentang Tipologi Siklus Hidup Pariwisata berdasarkan Teori Butler (1980), Danau Ranu Grati termasuk dalam kawasan wisata yang berada pada tahapan siklus hidup fase stagnan menuju decline. Hal ini menunjukkan bahwa kawasan wisata Danau Ranu Grati berada dalam fase perkembangan yang stagnan bahkan cenderung mengalami penurunan, untuk itu

diperlukan suatu konsep pengembangan wisata untuk menghidupkan kembali Danau Ranu Grati sebagai salah satu wisata alam di Kabapaten Pasuruan. [4]

Dalam mewujudkan usaha pariwisata dan pengembangan kawasan Ranu Grati maka diperlukan pembangunan kelembagaan pariwisata. Pembangunan kelembagaan pariwisata memiliki arti bahwa pengembangan kepariwisataan dilakukan terpadu antara pemerintah pusat, pemerintah daerah, pihak swasta, UMKM dan masyarakat lokal. Tujuan penulisan artikel ini adalah mendeskripsikan arahan pengembangan wisata Ranu Grati dilihat dari peran kelembagaan dengan metode (pemerintah, swasta dan masyarakat lokal) sebagai upaya merejuvenasi kawasan Ranu Grati yang saat ini berposisi di titik stagnan menuju decline.

Undang - Undang Nomor 10 Tahun 2009 tentang Kepariwisataan, mendefinisikan pariwisata sebagai berbagai macam kegiatan wisata dan didukung berbagai fasilitas serta layanan yang disediakan oleh masyarakat, pengusaha, Pemerintah, dan Pemerintah Daerah. Sedangkan kepariwisataan adalah keseluruhan kegiatan yang terkait dengan pariwisata dan bersifat multidimensi serta multidisiplin 
yang muncul sebagai wujud kebutuhan setiap orang dan negara serta interaksi antara wisatawan dan masyarakat setempat, sesama wisatawan, Pemerintah, Pemerintah Daerah, dan pengusaha. Dalam rangka meningkatkan penyelenggaraan kepariwisataan, Pemerintah melakukan koordinasi strategis lintas sektor pada tataran kebijakan, program, dan kegiatan kepariwisataan. Berdasarkan arahan pengembagan pariwisata dalam RTRW Kabupaten Pasuruan Tahun, dari segi jarak dan aksesibilitas Ranu Grati termasuk dalam zona IV, yang berpusat di Kecamatan Winongan, dimana dalam zona ini Ranu Grati juga menjadi kutub pertumbuhan bagi obyek wisata disekitarnya.

Beberapa best practice dalam pengembangan kawasan wisata alam atau danau yang menjadi referensi terkait rejuvenasi berbasis komunitas harus dimulai dari penguatan aspek kelembagaan. Salah satunya berupa upaya sosialisasi dari pihak pemerintah dalam penerapan peraturan yang telah ada, mengadakan penyuluhan dan membentuk kelompok sadar wisata, menjaga lingkungan danau, mempromosikan dan membina mitra wisata. Upaya sosialisasi dan menerapkan peraturan yang telah ada seperti Perda, bertujuan agar semua pihak yang terlibat dalam pengelolaan dan pemanfaatan pengembangan kawasan wisata mengetahui dan mendapatkan informasi mengenai peraturan tentang pengelolaan kelestarian kawasan wisata serta apa yang menjadi tujuan dalam pembangunan berkelanjutan dapat terlaksana. Kemudian, pembentukan kelompok sadar wisata bertujuan agar masyarakat sekitar memiliki kesadaran yang tinggi dalam meningkatkan potensi pariwisata.

\section{METODE PENELITIAN}

\section{A. Metode Analisis Data}

Metode Delphi bertujuan untuk mencapai konsesus dari serangkaian proses penggalian informasi. Dalam melakukan metode Delphi diperlukan pendapat dan judgment dari para ahli serta praktisi. [5] Metode ini dilakukan dengan menyebar kuisioner kepada responden yang berisikan daftar kriteria terkait indikator penyebab kurang berkembangnya kegiatan pariwisata Ranu Grati.

Analisa ini dilakukan dengan cara mengkomparasikan tinjauan kebijakan, best practice, serta hasil wawancara dengan stakeholder untuk kemudian diklasifikasikan ke dalam empat kuadran qudriple helix. [9] Konsep pengembangan yang dihasilkan nantinya akan disesuaikan pada aspek fisik lingkungan, sosial, ekonomi dan pariwisata dengan konsep pendekatan wilayah, yang artinya pengembangan kawasan Ranu Grati akan terintegrasi dengan wilayah yang ada di sekitarnya (konsep zonasi).

\section{HASIL DAN PEMBAHASAN}

A. Identifikasi faktor penyebab kurang berkembangnya kawasan wisata Ranu Grati dengan menggunakan metode Delphi

Hasil yang didapatkan dari proses penyusunan faktor yang berpengaruh terhadap menurunnya kondisi kawasan wisata alam Ranu Grati, Pasuruan terutama dari variabel kelembagaan ditampilkan pada Tabel 1 berikut.

Tabel 1.

Faktor Penyebab Penurunan Wisata Ranu Grati dari Sisi Kelembagaan

\begin{tabular}{|c|c|c|}
\hline No. & Aspek & "Arahan Kesesuaian \\
\hline 1 & Potensi SDM & $\begin{array}{l}\text { a. Jumlah sumber di Kecamatan } \\
\text { untuk dikembangkan guna } \\
\text { mendukung kepariwisataannya } \\
\text { b. Jumlah sumber daya manusia yang } \\
\text { belum diimbangi dengan kualitasnya }\end{array}$ \\
\hline 2 & Peran Serta Masyarakat & $\begin{array}{l}\text { a. Peran serta masyarakat belum } \\
\text { menyeluruh } \\
\text { b. "Sense of belonging" } \\
\text { masyarakat terhadap Danau Ranu } \\
\text { Grati cenderung rendah }\end{array}$ \\
\hline 3 & $\begin{array}{l}\text { Koordinasi } \\
\text { Stakeholder }\end{array}$ & $\begin{array}{l}\text { a. Pelaksanaan kegiatan } \\
\text { pembinaan, pengembangan dan } \\
\text { pemberdayaan masyarakat di Grati } \\
\text { oleh instansi terkait, berjalan sendiri } \\
\text { sendiri } \\
\text { b. Ketidaksinergisan antar } \\
\text { stakeholder memicu konflik sosial } \\
\text { c. Ketidaksinergisan antar } \\
\text { stakeholder memicu konflik } \\
\text { penggunaan lahan secara spasial }\end{array}$ \\
\hline
\end{tabular}

B. Rumusan arahan pengembangan kawasan wisata Ranu Grati dari segi kelembagaan dengan metode pendekatan "quadriple helix"

Hasil yang didapatkan dari penyusunan konsep pengembangan Ranu Grati mencakup perumusan zonasi pengembangan mikro yang berada pada tiga wilayah administrasi Kelurahan Grati Tunon, Desa Ranu Klindungan dan Desa Sumber Dawesari kemudian diintegrasikan dengan aspek kelembagaan yang dapat mendukung implementasi aktivitas di setiap zona. [1]

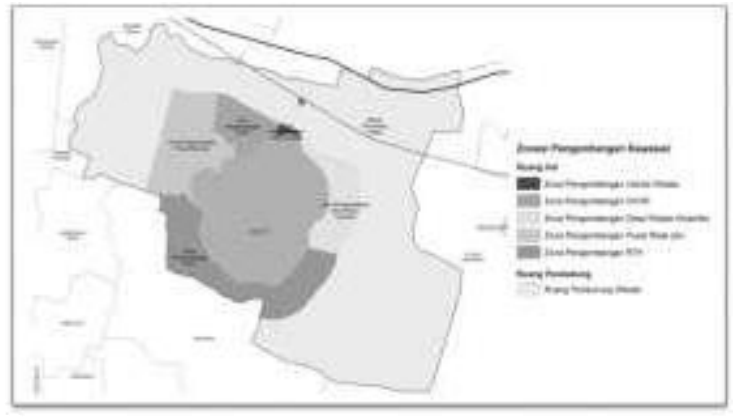

Gambar 1. Kesesuaian lahan untuk pengembangan perumahan dan kawasan permukiman

Pada Gambar 1 disajikan zonasi pengembangan mikro di kawasan Ranu Grati yang meliputi:

1. Ruang Inti, meliputi:

a. Zona Pengembangan Utama Wisata

Zona tersebut diperuntukkan untuk secara maksimal meningkatkan kualitas sarana-prasarana dasar wisata, revitalisasi kawasan serta peningkatan dan pembaruan daya tarik kawasan. Apabila masing- masing pengembangan tersebut diintegrasikan terhadap penguatan kelembagaan pariwisata maka dapat dilakukan pembagian tugas dan fungsi pihak terkait sebagaimana pada tabel berikut ini. 
Tabel 2.

Integrasi Pengembangan Zona Utama Wisata terhadap Penguatan Kelembagaan Pariwisata melalui Pembagian Tugas dan Fungsi Pihak Terkait

\begin{tabular}{l} 
Konsep Pengembangan \\
\hline Pengembangan Utama Wisata, \\
meliputi: \\
- Pintu gerbang \\
- Lahan parkir \\
- Kios souvenir \\
- Loket tiket \\
- Wisata Orientasi Kawasan \\
- Pendopo \\
- Rehabilitasi Makam \\
- Floating dock \\
- Floating auditorium \\
- Dermaga \\
- Kapal motor \\
- Atraksi air mancur \\
Lampu lampion
\end{tabular}

Konsep Pengembangan Fungsi Kelembagaan

a. Dinas Kebudayaan dan Pariwisata Kabupaten Pasuruan:

- Berkordinasi dengan dinas teknis untuk pelaksanaan pembangunan fasilitas/sarana wisata kawasan Ranu Grati

- Menyusun kalender wisata Kawasan Ranu Grati

- Membuat Peta Orientasi Wisata Kawasan Ranu Grati

- Melakukan pembinaan promosi dan kegiatan wisata kepada masyarakat sekitar untuk mengemas nilai budaya dan sejarah dalam seni pertunjukan

- Mengelola kegiatan wisata dari ticketing, pelayanan wisata kapal motor beseta safety atau penjaminan keamanan dan keselamatan wisatawan

- Melakukan pembangunan floating dock, floating auditorium dan dermaga

- Melakukan kegiatan operasional atraksi air mancur dan lampu lampion di sepanjang floating dock

b. Dinas Pekerjaan Umum Perumahan dan Kawasan permukiman:

- Melakukan pembangunan pintu gerbang, lahan parkir, kios souvenir, loket tiket, gardu pandang dan air mancur sesuai proyeksi jumlah pengunjung

c. Dinas Sosial Kabupaten Pasuruan

- Melakukan rehabilitasi makam di lokasi wisata Ranu Grai

- Melakukan penyelidikan asal usul makam di lokasi wisata Ranu Grati

\section{b. Zona Pengembangan One Village One Product (OVOP) Telur Bebek}

Zona tersebut diperuntukkan dalam pengembangan UMKM Unggulan Telur Bebek dengan berbagai hasil olahannya. Pengembangan ini bertujuan meningkatkan partisipasi masyarakat lokal dalam mengembangkan potensi sumber daya lokal yang dapat dipasarkan di dalam zona utama wisata maupun luar kawasan.

Tabel 3.

Integrasi Pengembangan OVOP Telur Bebek terhadap Penguatan Kelembagaan Pariwisata melalui Pembagian Tugas dan Fungsi Pihak

\begin{tabular}{|c|c|}
\hline Konsep Pengembangan & $\begin{array}{c}\text { Konsep Pengembangan Fungsi } \\
\text { Kelembagaan }\end{array}$ \\
\hline $\begin{array}{cc}\text { Pengembangan OVOP meliputi: } \\
\text { - } & \text { Area produksi } \\
\text { - } & \text { Area pengolahan } \\
\text { - } & \text { Area pemasaran }\end{array}$ & $\begin{array}{l}\text { a. Dinas Koperasi dan UKM } \\
\text { Kabupaten Pasuruan: } \\
\text { - Melakukan pembinaan pelaku } \\
\text { UKM telur bebek dari produksi } \\
\text { hingg pemasaran } \\
\text { - Melakukan penentuan dan } \\
\text { penataan lokasi produksi, } \\
\text { pengolahan dan pemasaran } \\
\text { - Memberikan rekomendasi } \\
\text { produk olahan telur bebek yang } \\
\text { variatif }\end{array}$ \\
\hline
\end{tabular}

b. Dinas Kebudayaan dan Pariwisata Kabupaten Pasuruan:

- Menyediakan tempa pemasaran produk UKM

- Melakukan promosi produk khas UKM kepada wisatawan

\section{c. Zona Pengembangan Desa Wisata Keramba}

Zona tersebut diperuntukkan dalam mengendalikan kegiatan budidaya perikanan sekaligus mengemasnya sebagai daya tarik wisata alam berupa kegiatan pemancingan, kuliner, pemasaran hasil olahan ikan khas Danau Ranu Grati dan hasil budidaya perikanan keramba yang dapat dijadikan wisata edukasi.

$$
\text { Tabel } 4 .
$$

Integrasi Pengembangan Zona Desa Wisata Keramba terhadap Penguatan Kelembagaan Pariwisata melalui Pembagian Tugas dan Fungsi Pihak Terkait

\begin{tabular}{|c|c|}
\hline Konsep Pengembangan & $\begin{array}{c}\text { Konsep Pengembangan Fungsi } \\
\text { Kelembagaan }\end{array}$ \\
\hline $\begin{array}{l}\text { Pengembangan Desa Keramba } \\
\text { meliputi: } \\
\text { - Floating dock } \\
\text { - Food court } \\
\text { - Petak keramba tancap } \\
\text { - Petak keramba jaring apung (KJA) } \\
\text { - Gardu pandang } \\
\text { - Ranu Grati branding sign }\end{array}$ & $\begin{array}{l}\text { a. Dinas Pariwisata } \\
\text { Pasuruan: } \\
\text { - } \text { Melakukan pembangunan floating } \\
\text { dock } \\
\text { - Melakukan kegiatan operasional } \\
\text { lampu lampion di sepanjang } \\
\text { floating dock terkait } \\
\text { - Berkoordinasi dengan tran teras } \\
\text { dalam pengembangan desa keramba } \\
\text { sebagai daya tarik wisata khas } \\
\text { Kawasan Ranu Grati } \\
\text { b. Dinas Kelautan dan } \\
\text { Kabupaten Pasuruan: } \\
\text { - Melakukan penataan keramba } \\
\text { - Melakukan } \\
\text { pembudidaya keramba dan nelayan } \\
\text { dalam hal produktivitas hingga } \\
\text { kewajiban masing-masing pihak } \\
\text { - Mengawasi dan mengelola } \\
\text { pemasaran hasil perikanan }\end{array}$ \\
\hline
\end{tabular}

\section{d. Zona Pengembangan Pusat Riset dan Exhibition}

Zona tersebut diperuntukkan sebagai fungsi penelitian, pengawasan, konservasi sekaligus pusat pameran dengan mengikutsertakan peran masyarakat seperti kelompok pembudidaya keramba, nelayan, pelaku UMKM, kelompok pengawas masyarakat dan pelestari budaya untuk melindungi dan meningkatkan citra kawasan dari sisi konservasi alam dan budaya khas Kawasan Ranu Grati.

Tabel 5.

Integrasi Pengembangan Zona Pusat Riset dan Exhibition terhadap Penguatan Kelembagaan Pariwisata melalui Pembagian Tugas dan Fungsi Pihak Terkait

\begin{tabular}{|c|c|}
\hline Konsep Pengembangan & $\begin{array}{c}\text { Konsep Pengembangan Fungsi } \\
\text { Kelembagaan }\end{array}$ \\
\hline $\begin{array}{l}\text { Pengembangan Pusat Riset dan } \\
\text { Exhibition, meliputi: } \\
\text { - Balai penelitian } \\
\text { - Balai pameran (Exhibition) }\end{array}$ & 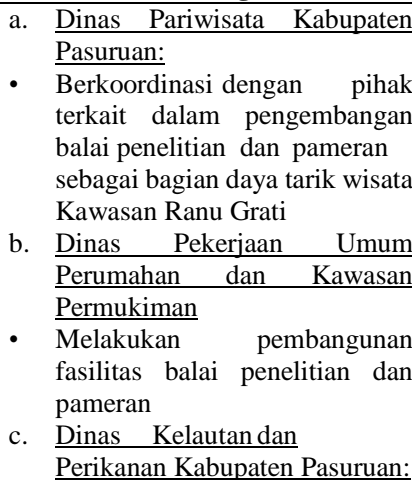 \\
\hline
\end{tabular}




\begin{aligned} & \hline $\begin{array}{l}\text { Melakukan penelitian perairan } \\ \text { Danau Ranu Grati } \\ \text { Melakukan penelitian rekayasa } \\ \text { budidaya perikanan }\end{array} \\ &$ d. $\begin{array}{l}\text { Dinas Lingkungan Hidup } \\ \text { Kabupaten Pasuruan penelitian }\end{array} \\ & . \quad \begin{array}{l}\text { Melakukan an manan air melalui water } \\ \text { pengolahan } \\ \text { management Danau Ranu Grati } \\ \text { Melakukan upaya peningkatan } \\ \text { kualitas ekologi Danau Ranu } \\ \text { Grati }\end{array} \\ &$\hline \hline\end{aligned}

\section{e. Zona Pengembangan Ruang Terbuka Hijau}

Zona tersebut diperuntukkan sebagai penyediaan lahan resapan, lahan penyangga perairan danau (fungsi sempadan danau) dengan tetap memberikan ruang interaksi terhadap masyarakat dan wisatawan melalui penyediaan jalur pejalan kaki sebagai jogging track.

$$
\text { Tabel } 6 .
$$

Integrasi Pengembangan Zona Ruang Terbuka Hijau terhadap Penguatan Kelembagaan Pariwisata melalui Pembagian Tugas dan Fungsi Pihak Terkait

\begin{tabular}{|c|c|}
\hline Konsep Pengembangan & $\begin{array}{l}\text { Konsep Pengembangan Fungsi } \\
\text { Kelembagaan }\end{array}$ \\
\hline 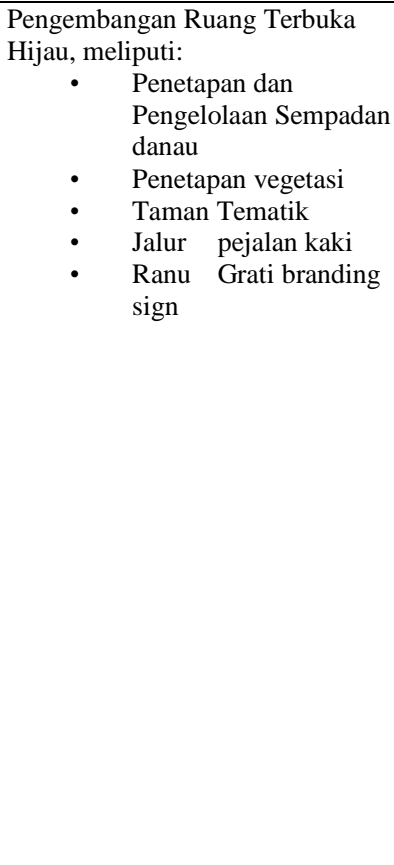 & 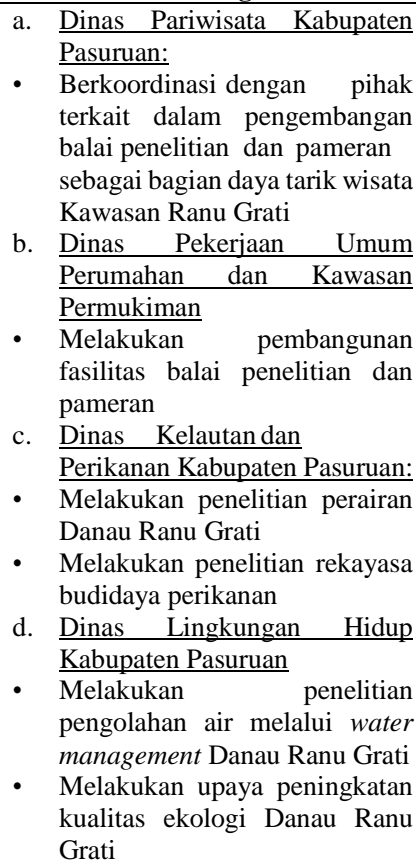 \\
\hline
\end{tabular}

\section{Ruang Pendukung}

Ruang pendukung berupa wilayah pendukung kegiatan di ruang inti seperti halnya penyediaan sarana-prasarana pendukung wisata seperti penginapan, rumah makan, kantor jasa perjalanan, sebagai berikut.

Tabel 7.

Integrasi Pengembangan Ruang Pendukung terhadap Penguatan Kelembagaan Pariwisata melalui Pembagian Tugas dan Fungsi Pihak Terkait

Konsep Pengembangan Konsep Pengembangan Fungsi Kelembagaan

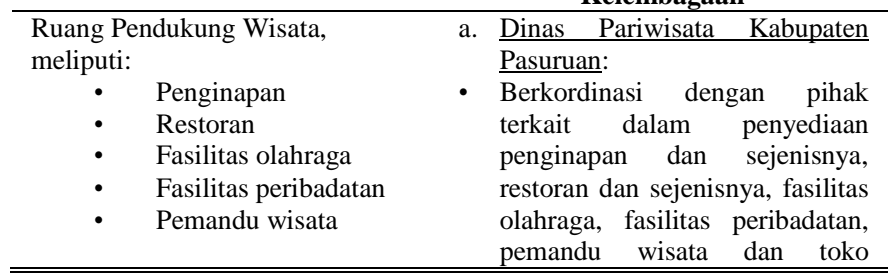

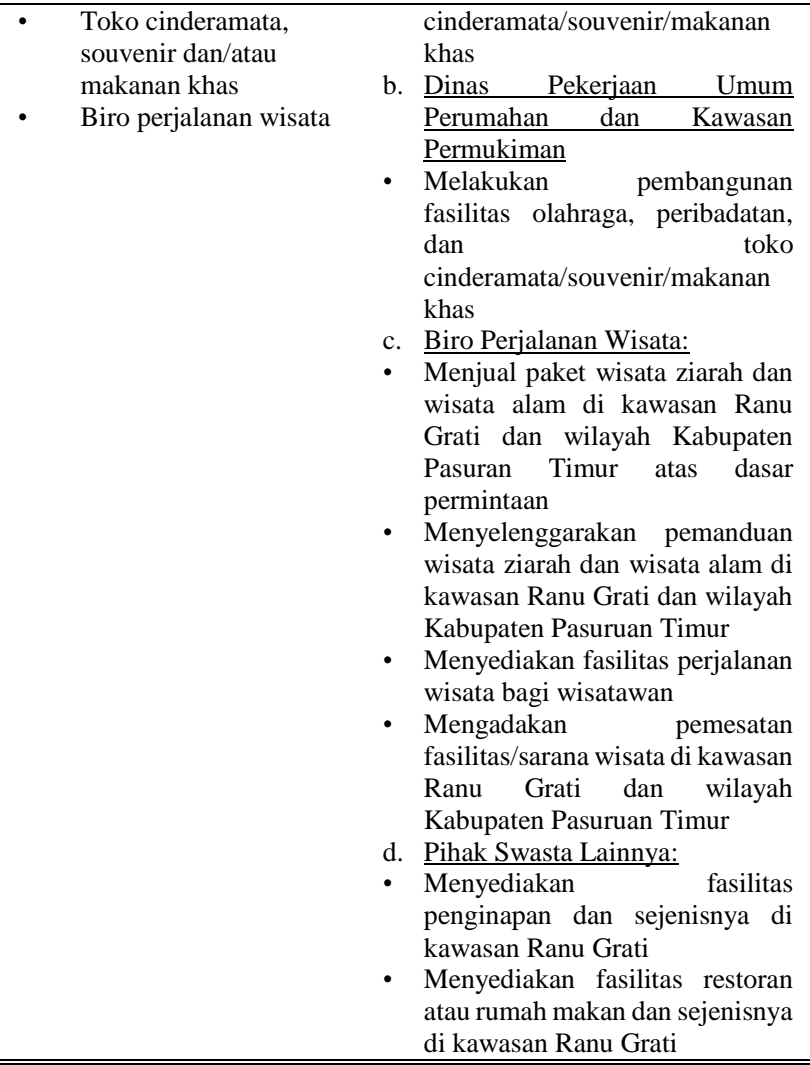

Berdasarkan konsep pengembangan mikro maka arahan pengembangan Kawasan Ranu Grati untuk kesiapan kelembagaan pariwisata adalah sebagai berikut.

Tabel 8.

Integrasi Pengembangan Ruang Pendukung terhadap Penguatan Kelembagaan Pariwisata melalui Pembagian Tugas dan Fungsi Pihak Terkait

\begin{tabular}{cl}
\hline \hline No. & \multicolumn{1}{c}{ Arahan } \\
\hline 1 & $\begin{array}{l}\text { Melakukan pemantapan unit pelaksana dan/atau badan } \\
\text { pengelola yang memiliki kepentingan di Kawasan Ranu Grati }\end{array}$ \\
\hline 2 & Membentuk badan pengawas pemanfaatan Kawasan Ranu Grati \\
\hline 3 & Merintis organisasi UMKM beserta pengurus sentra UMKM Grati \\
\hline 4 & $\begin{array}{l}\text { Memperjelas tugas dan fungsi Pokdarwis dalam mendukung } \\
\text { kegiatan pariwisata }\end{array}$ \\
\hline 5 & $\begin{array}{l}\text { Mewujudkan fungsi, kegiatan dan kewajiban yang sinergis antar } \\
\text { kelompok masyarakat binaan }\end{array}$ \\
\hline \hline
\end{tabular}

\section{KESIMPULAN}

Pengembangan konsep kelembagaan memiliki peran strategis dalam rejuvenasi kawasan wisata alam Ranu Grati di Kab. Pasuruan. Ditemukan bahwa faktor yang berpengaruh terhadap menurunnya kondisi kawasan wisata Ranu Grati meliputi potensi SDM yang belum seimbang, peran serta masyarakat yang masih rendah, dan koordinasi antar stakeholder yang kurang optimal. Faktor tersebut berpengaruh dalam penyusunan zonasi kawasan wisata Ranu Grati yang terintegrasi dengan konsep pengembangan fungsi kelembagaan yang terbagi dalam ruang inti dan ruang pendukung. Kelembagaan pariwisata Ranu Grati diarahkan secara kolaboratif di masing-masing zona pengembangan kawasan. Kolaborasi kelembagaan yang melibatkan pemerintah, swasta, masyarakat dan komunitas dibangun berdasarkan partisipasi dan peranan masing-masing pihak. 


\section{DAFTAR PUSTAKA}

[1] Badan Perencanaan Pembangunan Daerah Kabupaten Pasuruan. Rencana Induk Pengembangan Pariwisata Dan Ekonomi Kreatif Kabupaten Pasuruan Tahun 2014-2024

[2] Dinas Pariwisata dan Kebudayaan Kabupaten Pasuruan. Pariwisata Dalam Angka Tahun 2014.

[3] Pasuruan, Dinas Kebudayaan Dan Pariwisata Kabupaten. 2013. Objek Wisata Alam. Accessed Oktober 2, 2015.

[4] Tambunan, T. D. 2016. Pengembangan Kawasan Wisata Alam Berdasarkan Tipologi Siklus Hidup Pariwisata Di Kabupaten Pasuruan (Doctoral dissertation, Institut Teknologi Sepuluh Nopember).

[5] Ciptomulyono, U. 2001. Integrasi Metode Delphi dan Prosedur Analisis Hierarkhis untuk Identifikasi dan Penetapan Prioritas Objektif / Kriteria Keputusan. Majalah IPTEK Jurnal Pengetahuan Alam dan Teknologi, 12(1).

[6] http://disbudpar.pasuruankab.go.id. Department of European Paintings. "Architecture in Renaissance Italy." In Heilbrunn Timeline of Art History. New York: The Metropolitan Museum of Art, 2000-.

[7] Utama, Analisis Siklus Hidup Destinasi Pariwisata Bali: Kajian Ekonomi Pariwisata Terhadap Destinasi 2012.

[8] Yoeti, Oka A. 1996. Pemasaran Pariwisata. Bandung: Angkasa.

[9] Rumidi, Sukandar. 2006. Metodologi Penelitian Petujuk Praktis Untuk

[10] Puspito, Atras Radifan. 2015. Pengembangan Kawasan Agrowisata Melalui Pendekatan City Based Tourism di Kecamatan Bumiaji Kota Batu. Surabaya: Institut Teknologi Sepuluh Nopember.

[11] Pertiwi, Ratih. n.d. "Planning \& Development of Tourism: Pola Perencanaan \& Pengembangan Kawasan Lovina, Di Wilayah Bali Utara."

[12] Fandeli, Chafid. 1995. Dasar-Dasar Manajemen Kepariwisataan Alam. istepi Yogjakarta: Liberty

[13] Adiguna, Wildan. 2013. Kajian Daya TarikWisata Terkait Perkembangan Obyek Wisata Goa Pindul. Yogyakarta : Universitas Gadjah Mada

[14] Sugiyono. "Metode Penelitian Kuantitatif, Kualitatif dan R\&D". Bandung: Alfabeta. (2011).

[15] Evans, Peter. (2002). Improving The Housing Environment and Delivering 'Sustainable Communities. Birmingham : Groundwork Foundation

[16] Yoeti, O. A. (2002). Perencanaan Strategis pemasaran daerah tujuan wisata. Jakarta: Pradnya Paramita.

[17] Boud-Bovy, Manuel \&Lawson, Fred, 1977, Tourism and Recreation Development, Boston. CBI Publishing Company.

[18] Campbell, L and A. Vanio, 2003, Participatory Development and Community Based Conservation : opportunities Missed for Lessons Learend. Human Ecology

[19] Triambodo, S., \& Damanik, J. 2015. Analisis Strategi Penguatan Kelembagaan Desa Wisata Berbasis Ekonomi Kreatif (Studi di Desa Wisata Kerajinan Tenun Dusun Gamplong, Desa Sumberrahayu, Kecamatan Moyudan, Kabupaten Sleman, DIY). Universitas Gadjah Mada, Yogyakarta

[20] UNDP. 1997. Capacity Development. Manajemen Development and Governance Division. Technical Advisory Paper No. 2.

[21] Hamzah, A., \& Khalifah, Z. 2012. Community capacity building for sustainable tourism development: Experience from Miso Walai homestay. Community Capacity Building, 2, 1-10.

[22] Fandeli, C, 2003, Dasar-Dasar Pengembangan Manajemen Kepariwisataan Alam. Penerbit Liberty, Yogyakarta. 